\title{
Incorporating Javanese Gamelan Music As Democratic Pedagogy: A Junior High School Social Studies Teacher's Perspective
}

\author{
Yayuk Mardiati ${ }^{1}$, Wasino ${ }^{2}$, Dhanang Respati Puguh ${ }^{3}$, Eko Handoyo $^{4}$ \\ \{ymardiati@gmail.com ${ }^{1}$, swasino@gmail.com ${ }^{2}$, dhanang_puguh@yahoo.com ${ }^{3}$, eko_pkn@yahoo.co.id ek $^{4}$ \}
}

Social Science Study Program, Graduate School, University Negeri Semarang, Indonesia ${ }^{1,2,4}$, Faculty of Humanities, Diponegoro University, Indonesia ${ }^{3}$

\begin{abstract}
Previous research of Javanese gamelan emphasized theory, history, and culture, but there are no studies integrating gamelan music as instruction to enhance learners' democratic habits of mind. The purpose of the study is to examine how junior high school teachers perceive Javanese gamelan as a method of cultivating democratic thinking and values in social studies. This study employed qualitative analysis which asked social studies teachers to respond questions about elements of democracy when they integrate Javanese gamelan music in their social studies classroom. This phenomenological study obtained data from six purposive selected participants in two junior high schools which described the result through focus group discussion and interview.The result of the study identified five themes from the data: (1) rights (2) responsibility (3) participation, (4) leadership, and (5) cooperation. Implications for collaboration between gamelan teachers, teacher educators, and future research are considered.
\end{abstract}

Keywords: Democratic Pedagogy, Integration, Javanese Gamelan, Social Studies

\section{Introduction}

There have been growing on interdisciplinary studies of art-based teaching, including music in social studies. Some scholars and educators believe that using an integrated or interdisciplinary approach, which construct or tie new knowledge across subjects enhances students' critical thinking skills and enlarges students' understanding of the content areas they study. ${ }^{1} 2$ Studies incorporating songs and song lyrics are used as primary source in learning history. ${ }^{3}$ As recently found that by integrating music in in social studies enables junior/senior high school students' interest to analyze symbols and meaning in a culture. ${ }^{2}$ Burstein's study

\footnotetext{
${ }^{1}$ Eisner, A.: The Arts and the creation of mind. In chapter 4, What the arts teach and how it shows. pp. 70-92. Yale University Press (2002)

${ }^{2}$ Mangram, J.R. \& Weber, R.L.: Incorporating music into the social studies classroom: A qualitative study of secondary social studies teachers. The Journal of Social Studies Research. pp. 3-21. (2012)

${ }^{3}$ Pellegrino, A.M. \& Lee, C.D.: Let the music play: Harnessing the power of music for history and social studies classrooms. Information Age Publishing (2003)
} 
examined that by integrating cultural anthropology, especially music, dance, and artifact in social studies enables students to develop understanding of history and culture of other countries. ${ }^{4}$ Several ethnomusicologists analyzed Jazz music related to democracy, such as freedom, spontaneity, and social dimension. ${ }^{6}$ Other ethnomusicologist argued that music education should not just be about imparting knowledge, but also about instilling compassion and care for self and others. ${ }^{7}$ This argument implies that music can be utilized as democratic pedagogy. Empirical study conducted in Central Florida, United States of America explored the effectiveness of the implementation of Western music integration in the middle school social studies classroom. ${ }^{8}$ This study examines junior high school teachers' perspective of integrating gamelan music into social studies as democratic pedagogy. Gamelan, one of world musics contains within its compositional arrangements, unique elements of democratic behavior. By having teacher-subjects research, observe, and utilize gamelan into social studies, teachers evoke sophisticated thinking skills and discussion of democratic values.

\section{Methods}

The phenomenological case study method was employed in a particular extracurriculer activities on gamelan music performance. ${ }^{9}$ Some scholars note that the "the primary objective of a phenomenological study is to explicate the meaning, structure, and essence of the lived experiences of a person, or a group of people around a specific phenomenon" (p. 11). ${ }^{10}$ This phenomenological study obtains data from six social studies teachers in two state junior high schools three and five, Trenggalek sub-district, East Java, Indonesia to elucidate their perspective of incorporating gamelan music in social studies as a means of cultivating democratic values. The focus group technique used in this study consisted of 3 females and 1 male of social studies teachers and 2 males of gamelan music teachers. The focus group lasted about one and half hours. They were audio recorded and fully transcribed. The selected participants in this study used pseudonyms and were employed at the beginning of the data collection, throughout all the data collection, and the research report. All of the participants had 10 years teaching experience and none of the participants had ever partaken in a research focus group. A semi-structured, open-ended format was provided for flexible conversation ${ }^{9}$

\footnotetext{
${ }^{4}$ Burstein, J.H.: Integrating arts and expressive culture in social studies curriculum. Social Studies Research and Practice, 9 (2), pp. 132-144. (2014)

${ }^{5}$ Alperson, P.: A Topography of improvisation. The Journal of Aesthetics and Art Criticism, 6 (3), pp. 273-280. (2010)

${ }^{6}$ Mirón, L., Gines, V. \& Boselovic, J.L.: (2015). Jazz aesthetics \& the democratic imperative in education: A dialogue. Open Review in Educational Research. Taylor \& Francis 12: 1. pp. 182-193, (2015) DOI: 10.1080/23265507.2015.1074868

7 Krüger, S.: Democratic pedagogies: Perspective of ethnomusicology and world music education contexts in the United Kingdom. Etnnomusicology, Vol. 55. No. 2. pp. 280-305. (2011)

${ }^{8}$ Skeen, N.: An Exploration of the implementation of music integration in the middle school social studies classrooms. Master Thesis. The University of Central Florida (2015)

${ }^{9}$ Moustakas, C.:Phenomenological research method. Thousand Oaks, CA: Sage (1994)

${ }^{10}$ Christensen, L. B., Johnson, R. B., \& Turner, L. A.: Methods, designs, analysis (11th ed). Boston, MA: Allyn \& Bacon (2010)
} 
The focus group were asked the following questions: a. What democracy means to you? b. Do you use (any) music in social studies classroom? c. Do you use gamelan music in social studies classroom? d.What constitutes democratic values when incorporating gamelan music in social studies?

\section{Results and Discussion}

This study aimed to examine middle school teachers' perspective in incorporating Javanese gamelan music as democratic pedagogy in social studies. Emerging five themes of democratic values in Javanese gamelan context: rights, responsibility, participation, leadership, and cooperation are discussed below:

Theme one: rights in gamelan context

The participants define democracy as rights. Rights used in gamelan context include (a) right in choosing the gamelan instruments, (b) right in switching the gamelan instruments, and (c) right in deciding the best instrument in gamelan playing. The following participants commented on their understanding of rights as element of democratic values when incorporating gamelan music in social studies:

I let students immerse into gamelan playing. During the learning process, I expect each student to learn not only a specific gamelan instrument. He or she also learns each instrument from the simplest of the saron (seven keys lie atop a through resonator) to the most complex or high density elaborating instrument of the bonang (a double-row rack of small horizontal kettle gongs) (Pak Adji, gamelan teacher).

I let students shift to other instruments so that they not only experience interrelatedness of the style's structure but they also enjoy greater flexibility (Pak Slamet, gamelan teacher).

In gamelan playing, I think students have rights to play any gamelan instruments or to be sindhen (female singer) or penggerong (male chorus) (Bu Heni, social studies teacher).

With the teachers' guidance, students' rights to learn various skills through gamelan playing encourage exploration of musical form. ${ }^{11}$ In addition, with the gamelan teacher's role as apprentice who lets students shift to other instruments encourages spontaneity in the course of gamelan production.

Theme two: responsibility in gamelan context

Besides rights, responsibility plays an important role in gamelan playing. The following participants have variety of responses when asked their opinions about responsibility in incorporating gamelan music in social studies.

I encourage students to come on time in gamelan playing (Pak Gunawan, social studies teacher).

Students should be responsible of the instruments they choose, and therefore they have to follow the rules, like how to play the loud or soft sounding of gamelan instruments which would affect the quality of sound (Pak Adji, gamelan teacher).

\footnotetext{
${ }^{11}$ Brinner, B.: Knowing music, making music: Javanese gamelan and the theory of musical competence and interaction. Chicago: The University of Chicago Press (1995)
} 
I think students who choose to be sindhèn (female singers) have to be responsible to maintain their voice in creating céngkok (improvisation) (Bu Narti, social studies teacher).

Playing gamelan teaches students to be responsible for themselves (individuals) and for others (social), regarding rules (i.e: being on time), making choices which will affect themselves and others, and being creative. Playing gamelan instruments is analogous to the democratic action since the musicians exercise their individuality within the framework of rules governing the music and the rules of a particular composition.

Theme three: participation in gamelan context

Gamelan music making requires a group endeavor involving participation of more than two dozen musicians, including sindhèn (female singers) and penggérong (male chorus) who perform together for hours on end. Participants who observed the students involved in gamelan playing commented as the following:

Some students come on Wednesdays and Saturdays after school to participate in gamelan practice as extracurriculer activity (Bu Imbang, social studies teacher).

Some exceptional students (Indonesian seniman) who master more than one gamelan instruments often participate in playing balungan (saron family which functions as skeletal melody) or bonang (the complex and elaborating small kettle gongs which must be played with two hands using interlocking pattern) (Pak Adji, gamelan teacher)

Participation of individuals in gamelan music making is critical since each gamelan instrument has different characteristic on how to play it in unison. Studies on musical competence and musical interaction in Javanese gamelan states that in order for the Javanese gamelan to work require the social competence of participating members. ${ }^{11}$

Theme four: leadership in gamelan context

In a group of gamelan musicians there is no visible conductor in a course of gamelan performance. The following participants' responses indicate their understanding of leadership in gamelan performance which can be adapted as democratic pedagogy.

You cannot really see the conductor who leads the gamelan orchestra, but you can hear the kendang (hand-drums) player who gives a clue when you have to speed up or to slow down, or sometimes to make immediate stop depending on the gendhing (piece) (Bu Heni, social studies teacher).

In gamelan performance, each gamelan player can use notation, but he or she should also listen to the kendhang player, if not you do not know how to stop (Pak Lucky, gamelan teacher).

Sometimes I feel confused to see the bonang player or the sindhen who have more freedom in creating improvisation introduce the gendhing (piece), but at the same time they have to listen to the kendhang (Pak Gunawan, social studies teacher)

The participants' responses indicate that musically, the kendhang player whose role as an audible conductor knows variety of cues in a certain piece. Democratically, the kendhang player whose servant leadership tends to listen all participating members. The similar part also applies to the bonang player and the sindhen who have greater freedom in creating improvisation but their freedom was governed by mediated authority of the kendhang player through subtle cues which tends to invite (Javanese-ngajak), rather than commending. As the 
folowing scholar who emphasis gamelan performance states "if the irama, or the tone is to leap, or to be cut off, the process must not be jerky and the emotional quality must still be even." 11 This notion implies the smoothness as preference in gamelan playing which reflects Javanese value of maintaining balance or peaceful state. Researcher links the importance of balance in Javanese social interaction to the musicians' choices of patterns. ${ }^{12} \mathrm{He}$ asserted that in keeping with the steady state ethos, one strives for balance and smoothness in fit and in flow through time. ${ }^{12}$ Gamelan, then, offers teachers a rich resource of developing elements of democratic values, fostering students' higher order thinking skills, and exercising democratic habits of mind.

Theme five: cooperation in gamelan context

Socially, musicians produce the sound of gamelan through an interdependent relationship to create harmony or peaceful state and cooperation. This social endeavor imbricates with democratic characteristics. The participants regard cooperation a performance ethics as follows:

I think if you play gamelan instruments you are not supposed to fight, you must be rukun (compatibility) to each other (Bu Narti, social studies teacher).

In gamelan playing, gotong royong (working together) is a must in order to be good (Pak Adji, gamelan teacher).

The participants' understanding of cooperation accords with the Javanese concepts of rukun and gotong royong which hold that differences of opinion and conflicting intentions are settled communally with a minimum friction. Consensus should be attained through indirect mediation and through established nonverbal modes of behavior.

These two concepts lead to the implication that in Javanese democratic life, consensus is attained through open-ended argument and discussion.

\section{Conclusion}

This study identified five themes; rights, responsibility, participation, leadership, and cooperation in which middle school teachers perceive when incorporating gamelan music as democratic pedagogy in social studies classroom. This research suggested participants more collaborative practice between social studies teachers and gamelan teachers. This study only involved middle school teachers. Other case studies would be important to consider for elementary and senior high school social studies teachers.

Acknowledgments. The author would like to deliver her greatest gratitude towards all the parties involved in this research. This study would not be completed without the supports and guidance of Professor Wasino, Dr. Dhanang Respati Puguh, and Dr. Eko Handoyo as the advisors, Pak Sarji and Pak Slamet as gamelan teachers, and Pak Supriyanto, Ibu Wilujeng, Ibu Helik and Ibu Endang as social studies teachers.

\footnotetext{
12 Sutton, R. A.: (1982). Variation in Javanese gamelan: Dynamics of a steady state. Ann Arbor: University Microfilms (1982)
} 


\section{References}

[1] Eisner, A.: The Arts and the creation of mind. In chapter 4, What the arts teach and how it shows. pp. 70-92. Yale University Press (2002)

[2] Mangram, J.R. \& Weber, R.L.: Incorporating music into the social studies classroom: A qualitative study of secondary social studies teachers. The Journal of Social Studies Research. pp. 321. (2012)

[3] Pellegrino, A.M. \& Lee, C.D.: Let the music play: Harnessing the power of music for history and social studies classrooms. Information Age Publishing (2003)

[4] Burstein, J.H.: Integrating arts and expressive culture in social studies curriculum. Social Studies Research and Practice, 9 (2), pp. 132-144. (2014)

[5] Alperson, P.: A Topography of improvisation. The Journal of Aesthetics and Art Criticism, 6 (3), pp. 273-280. (2010)

[6] Mirón, L., Gines, V. \& Boselovic, J.L.: (2015). Jazz aesthetics \& the democratic imperative in education: A dialogue. Open Review in Educational Research. Taylor \& Francis 12: 1. pp. 182-193, (2015) DOI: $10.1080 / 23265507.2015 .1074868$

[7] Krüger, S.: Democratic pedagogies: Perspective of ethnomusicology and world music education contexts in the United Kingdom. Etnnomusicology, Vol. 55. No. 2. pp. 280-305. (2011)

[8] Skeen, N.: An Exploration of the implementation of music integration in the middle school social studies classrooms. Master Thesis. The University of Central Florida (2015)

[9] Moustakas, C.:Phenomenological research method. Thousand Oaks, CA: Sage (1994)

[10] Christensen, L. B., Johnson, R. B., \& Turner, L. A.: Methods, designs, analysis (11th ed). Boston, MA: Allyn \& Bacon (2010)

[11] Brinner, B.: Knowing music, making music: Javanese gamelan and the theory of musical competence and interaction. Chicago: The University of Chicago Press (1995)

[12] Sutton, R. A.: (1982). Variation in Javanese gamelan: Dynamics of a steady state. Ann Arbor: University Microfilms (1982) 